\title{
Development of Bioformulation and its Application against Management of Thrips and Root Rot Disease of Mulberry, Morus alba
}

\author{
P. Mohanraj ${ }^{1 *}$, C.A. Mahalingam ${ }^{2}$ and R. Raghuchander ${ }^{3}$ \\ ${ }^{1}$ Department of Sericulture, The Forest College and Research Institute, \\ TNAU, Mettupalayam, India \\ ${ }^{2}$ Department of Entomology, TNAU, Coimbatore, India \\ ${ }^{3}$ Department of Plant Pathology, TNAU, Thiruvannamalai, India \\ *Corresponding author
}

\begin{tabular}{|c|c|}
\hline & A B S T R A C T \\
\hline & \multirow{6}{*}{$\begin{array}{l}\text { Silkworm gut bacterial isolates were identified by using } 16 \mathrm{~S} \text { rRNA gene sequence data } \\
\text { analysis. Total viable count, spore count and spore percentage were tested on selective NA } \\
\text { medium and recorded at different hours interval. The highest value of total viable count } \\
\text { was recorded }\left(420 \times 10^{8} \mathrm{CFU} / \mathrm{ml}\right) \text {, spore count was higher }\left(100 \times 10^{8} \mathrm{CFU} / \mathrm{ml}\right) \text { after } 72 \mathrm{~h} \text { of } \\
\text { inoculation. The sporulation percentage of } B \text {. Subtilis }(7.69,10.20,23.8 \text { and } 37.30) \text { was } \\
\text { found to gradually increase from } 24 \mathrm{~h} \text { to } 96 \mathrm{~h} \text { respectively. Enhancement of sporulation } \\
\text { process using in mixture, highest total viable counts }\left(190 \times 10^{8} \mathrm{CFU} / \mathrm{ml}\right) \text { and highest heat } \\
\text { resistant spore count }\left(183 \times 10^{8} \mathrm{CFU} / \mathrm{ml}\right) \text {. The spore percentage was } 96.3 \text { per cent in } \\
\text { mixture and lowest spore percentage was observed in } \mathrm{CaCl}_{2}\left(32 \times 10^{8} \mathrm{CFU} / \mathrm{ml}\right) \text {. Bacteria } \\
\text { survived even up to } 180 \text { days of storage with different survival percentage over the period. } \\
\text { The highest survivable percentage }(88.3 \%) \text { of viable cell count was recorded on } 30^{\text {th }} \text { day. } \\
\text { Evaluated bioformulation against pest and disease in mulberry. In thrips, highest } \\
\text { percentage of reduction over control was observed in } 100 \text { per cent }(86.95 \%) \text { followed by } 80 \\
\text { per cent ( } 80.43 \%) \text {, } 60 \text { per cent }(75.00 \%) \text { and } 40 \text { per cent }(64.13 \%) \text {. The endogenous } \\
\text { bacterial isolates of B. subtilis and B. tequilensis were tested individually to assess the } \\
\text { inhibition against the radial mycelial growth of } M \text {. phaseolina and } F \text {. oxysporum. The } \\
\text { bacterial isolates of B. subtilis recorded the least mycelial growth }(45.00 \text { mm) against } M \text {. } \\
\text { phaseolina. The least mycelial growth of } F \text {. oxysporum was recorded in treatment with } B \text {. } \\
\text { subtilis }(63.00 \mathrm{~mm}) \text {. }\end{array}$} \\
\hline & \\
\hline $\begin{array}{l}\text { Silkworm, Gut } \\
\text { bacteria, Thrips, } \\
\text { Macrophomina } \\
\text { phaseolina, } \\
\text { Fusarium } \\
\text { oxysporum. }\end{array}$ & \\
\hline Article Info & \\
\hline $\begin{array}{l}\text { Accepted: } \\
\text { 20 February } 2017 \\
\text { Available Online: } \\
10 \text { March } 2017\end{array}$ & \\
\hline & \\
\hline
\end{tabular}

\section{Introduction}

Microorganisms are a rich source of new metabolites with a wide variety of biological activities and some of them display significant practical applications. Earth is the planet of insects, as they are found in almost every corner of the earth. There exist more than one million insect species than any other animal species comprising $72.8 \%$ of all animals (Dillon and Dillon, 2006). One of the major features of insects is their extraordinary diversity in terms of numbers and morphological forms. In addition to their ability to survive in different ecological conditions, insect gut is a reservoir of complex microbial communities. These contribute to the host nutrition, growth, development and physiology. Apart from that they also play a key role for the stimulation of 
the immune system and resistance against the invading pathogens (Kehindeetal., 2011).The protective effect of the gut bacteria are termed as bacterial antagonism which is a significant component of host defense against pathogens. Gut bacteria has been documented to show antagonistic activity against pathogenic bacteria and fungi.

Function for biomass deconstruction from insect symbiotic microbiota is well characterized. Both herbivore insects and symbiotic microbes can secrete cellulytic enzymes for biomass deconstruction and hydrolysis (Ohkuma, 2003; Tokuda and Watanabe, 2007; Warnecke et al., 2007; Sun and Zhou, 2009). It has been controversial about which plays a more important role for biomass deconstruction, the symbionts or insect host itself. Despite the controversy, the importance of symbiotic microbes for biomass deconstruction has recently been established by various genome-level studies. In the present study, isolated the gut bacteria as of silkworm and developed the bio formulation against pest and disease of mulberry (Morusalba).

\section{Materials and Methods}

\section{Molecular identification of antagonistic bacterial isolates}

Among these six antagonistic bacterial isolates, two isolates which were found to be promising. They were subjected to further molecular studies done by Merck Millipore, Bangalore. The genomic DNA was extracted using geneiUltrapure ${ }^{\mathrm{TM}}$ bacterial genomic DNA purification kit KT162 Cat\# 612116200021730 and stored at $-20{ }^{\circ} \mathrm{C}$.

Each strain was identified to the genera by amplifying the $16 \mathrm{~S}$ rDNA fragment by polymerase chain reaction (PCR) using specific primers of Forward primer - 5' -
AGAGTTTGATCMTGGCTCAG - 3' and Reverse primer - 5' - TACGGYTACCTT GTTACGACTT-3'. The $1.5 \mathrm{~kb}$ fragment of $16 \mathrm{~S}$ rDNA was amplified in a thermocycler under the following conditions: initial denaturation at $94^{\circ} \mathrm{C}$ for $5 \mathrm{~min} ; 35$ cycles of $94^{\circ} \mathrm{C}$ for $30 \mathrm{sec} ; 55^{\circ} \mathrm{C}$ for $30 \mathrm{sec} ; 72^{\circ} \mathrm{C}$ for $1.30 \mathrm{~min}$ and final extension at $72^{\circ} \mathrm{C}$ for 10 min. The PCR reaction mixtures $(50 \mu \mathrm{l})$ contained $100 \mathrm{ng}$ of each primers, genomic DNA $20 \mathrm{ng}$, dNTP mix (2.5Mm each), tag buffer A (10X) 1x, taq polymerase enzyme $3 \mathrm{U}$ and double distilled water to make up the volume $50 \mu 1$. The PCR products were analyzed using electrophoresis on 1 per cent agarose gel and marked using 500bp DNA ladder as the size marker. After migration, gels were exposed to ultraviolet light (UV) to locate the amplified bands. The sequences were compared for similarity with reference sequences in genomic databases using BLAST.

\section{Production and optimization of Bacillus subtilis}

Bacillus subtiliswas grown on nutrient agar for $24 \mathrm{~h}, 48 \mathrm{~h}, 72 \mathrm{~h}$ and $96 \mathrm{~h}$ of cultivation on an orbital shaker at $150 \mathrm{rpm}$ at $300^{\circ} \mathrm{C}$. Both viable and heat - resistant spore counts were determined. For heat - resistant spore counts, cultures were heated at $80^{\circ} \mathrm{C}$ for $15 \mathrm{~min}$ to kill any vegetative cells present. Spores were then subsequently enumerated by plating aliquots of serial dilutions onto nutrient agar media which were incubated for 3 days at $30^{\circ} \mathrm{C}$.

\section{Multiplication of sporulation}

Nutrient broth medium was used as the basal medium on which more number of spores multiplied under sterilized condition. Total viable spore count and the spore percentage were determined after $72 \mathrm{~h}$ of cultivation as described before. 


\section{Preparation of Bacillus subtilis spores}

Bacillus subtiliswas grown on a modified nutrient medium supplemented with a mixture of $\mathrm{MnSO}_{4}, \mathrm{CaCl}_{2}, \mathrm{ZnSO}_{4}$ and $\mathrm{KCl}$ at a concentration of $500 \mu \mathrm{g} / \mathrm{mL}$ for 3 days on an orbital shaker at $150 \mathrm{rpm}$ till the maximum spore yield was produced. These were harvested and subsequently washed by repeated centrifugation at 10,000 rpmfor 20 min at $4{ }^{\circ} \mathrm{C}$ and resuspended in sterile distilled water (Warriner and Waites, 1999). Finally, the spore pellet was re-suspended in sterile distilled water and used as active material in different formulations. The final spore titer was $\geq 108 \mathrm{CFU} / \mathrm{mL}$.

\section{Formulation of Bacillus subtilis}

The inert carrier used in the formulations was talc. For $1 \%$ carboximethylcellulose (CMC) as binder, traces of sodium benzoate as stabilizer, $15 \% \mathrm{CaCo} 3$ as buffer and $0.25 \%$ of different enrichment materials were incorporated. The enrichment materials incorporated to be tested were: glucose, sucrose, mannitol, yeast and peptone. The inert carriers, enrichment and additive materials were mixed and sterilized by autoclaving. Twenty $\mathrm{mL}$ of spore suspension was added into them, mixed well under aseptic conditions, and then the mixtures were air dried in a laminar flow chamber for 48 hours. After drying, one $\mathrm{g}$ sample was removed for initial population counts. Powder formulations were then placed in plastic petri plates, sealed with parafilm, stored at room temperature and sampled for viability assessment.

\section{Viability assessment}

In the viability assessment, population counts of bacteria among various formulations were determined by serial dilutions from formulations and plated in triplicate on nutrient agar, and the CFU per gram of formulation were enumerated at monthly interval for 6 months.

\section{Evaluation of formulation against sericulture pest and disease}

\section{Bioassay study against mulberry pest of thrips}

Bacillus subtilis isolates were incubated at $30^{\circ} \mathrm{C}$ for $72 \mathrm{~h}$ in nutrient broth. After incubation, stock culture was diluted at different percentages $(40,60,80$, and 100$)$ by adding sterile phosphate-buffered saline, and $5 \mathrm{~mL}$ of the culture was centrifuged at 6,000 $\mathrm{rpm}$ for $10 \mathrm{~min}$. The pellet was re-suspended in $5 \mathrm{~mL}$ of sterilized phosphate-buffered saline and it was used for bioassays. Bioassays were carried out in two sets of pot cultured mulberry plants maintained separately in Mylar cages. Bacterial cultures were sprayed on a set of mulberry plants at different concentration and control was maintained separately. Thrips were collected from the infested mulberry garden and released by camel brush at 100 thrips per plant in treated and control pot cultured mulberry plants. The mortality of insects was recorded at $1^{\text {st }}, 3^{\text {rd }}, 7^{\text {th }}, 10^{\text {th }}$ days. Mortalities were corrected by Abbott's formula.

Screening of bacterial isolates for biocontrol potency against $M$. phaseolina and $F$. oxysporum by dual culture technique

The six isolates of bacterial culture obtained in this study were tested against the $M$. phaseolina and $F$. oxysporum by the dual culture technique. The mycelial disc of $5 \mathrm{~mm}$ diameter of bacterial isolates from a three-day old culture was placed one side $0.5 \mathrm{~cm}$ away from the edge of the petriplate containing PDA media, and the disc of M. phaseolina and F.oxysporum. A three-days old culture was placed on the opposite side, $6 \mathrm{~cm}$ apart from the bacterial streak. The plates were incubated at $24+2{ }^{\circ} \mathrm{C}$ for one week. The 
plates were observed at regular intervals for the radial growth of the pathogen and also the antagonistic bacterial isolates. The distance of inhibition zone was measured to the nearest whole millimeter.

The radial mycelial growth of the pathogen and per cent reduction over control was calculated by using the formula as follows

C - T
Per cent inhibition over control $=\frac{------}{\text { X } 100}$

Where,

$\mathrm{C}$ - mycelial growth of pathogen in control

$\mathrm{T}-$ mycelial growth of pathogen in dual plate

\section{Results and Discussion}

Development and $\begin{aligned} & \text { evaluation of } \\ & \text { bioformulation for pest and disease } \\ & \text { management }\end{aligned}$

\section{Molecular identification of antagonistic} silkworm gut bacteria

The isolates SGB1 and SGB2 were identified by $16 \mathrm{~S}$ rRNA gene sequence data analysis. The identification of the isolate was confirmed commercially by the Merck Millipore, a division of Merck KGaA, Darmstadt, Germany (Report enclosed). A BLAST search of the database indicated a close genetic relationship to other isolates of Bacillus sp. The phylogenetic tree was constructed and tree visualization was done by Molecular Evolutionary Genetics Analysis (MEGA) software version 4.0 (Plate 1a and 1b). Partial 16S rRNA gene sequence data analysis of strain SGB1 and SGB2 showed high arrangements between traditional and molecular identification as established by earlier traditional characterization, and the isolate was finally identified as B. subtilis and B. tequilensis.

\section{Development of commercial product}

Formulations generally composed of the active material must be preserved or maintained in viable condition to produce its biological effect; the carrier material may or may not include the incorporation of enrichment materials or additives.

Generally, amendments can be grouped as either carriers (fillers, extenders) or amendments that improve the chemical, physical, or nutritional properties of the formulated biomass (Schisler et al., 2004). The active material is mixed with carrier materials such as water, talc or others to make the formulation safer to handle, easier to apply and better suited for storage. In some formulations, enrichment materials comprising of nutrient-rich medium such as, molasses, trehalose, maltose and sucrose are incorporated to further enhance the viability of core (active) materials (Brar et al., 2006; Tu and Randall, 2005).

The commercial use of biocontrol agent requires inoculum that retains high cell viability and easily be transported and applied. The aims of formulating viable cells are to ensure that adequate cell viability is sustained to increase the efficacy of the cells and to facilitate the delivery and handling processes (Filho et al., 2001). For commercialization, a long shelf-life is an advantage for any inoculant (Fages, 1990 and 1992).

In the present study, total viable cell counts (TVC), spore count, spore percentage, enhancement of sporulation, effect of different carriers and amendments on survival of bacteria was carried out the highest value of total viable count was recorded $\left(420 \times 10^{8}\right.$ $\mathrm{CFU} / \mathrm{ml}$ ) after $72 \mathrm{~h}$ followed by $175 \times 10^{8}$ $\mathrm{CFU} / \mathrm{ml}$ at $48 \mathrm{~h}$ compared to 24 and $96 \mathrm{~h}$. Heat-resistant spore count was $100 \times 10^{8}$ 
$\mathrm{CFU} / \mathrm{ml}$ after $72 \mathrm{~h}$ of inoculation when compared to other durations. The sporulation percentage of B. subtilis (7.69, 10.20, 23.8 and 37.30) was found to gradually increase from $24 \mathrm{~h}$ to $96 \mathrm{~h}$ respectively. The total viable count and heat resistant spore count of B. subtilis was significantly higher at $72 \mathrm{~h}$ interval than other hour intervals $(24 \mathrm{~h}-65$ $\mathrm{TVC} \times 10^{8} \mathrm{CFU} / \mathrm{ml}$ and $5 \mathrm{HRSC} \times 10^{8}$ spore $/ \mathrm{ml}$; $48 \mathrm{~h}-175 \mathrm{TVC} \times 10^{8} \mathrm{CFU} / \mathrm{ml}$ and 18 $\mathrm{HRSC} \times 10^{8}$ spore/ml and in $96 \mathrm{~h}-75$ $\mathrm{TVC} \times 10^{8} \mathrm{CFU} / \mathrm{ml}$ and $28 \mathrm{HRSC} \times 10^{8}$ spore/ml) (Table 1).

As shown from table 2, incorporation of metals to the basal sporulating media generally increase the sporulation process, total viable counts were higher (190 $\left.\times 10^{8} \mathrm{CFU} / \mathrm{ml}\right)$ in mixture followed by $\mathrm{MnSO}_{4}$ $\left(145 \times 10^{8} \mathrm{CFU} / \mathrm{ml}\right)$ except for $\mathrm{CaCl}_{2} \quad(78$ $\times 10^{8} \mathrm{CFU} / \mathrm{ml}$ ) and this might be due to increasing of osmotic pressure of media which have positive effect on sporulation process, which is supported by the fact that certain transition metals including zinc ( $\mathrm{Zn})$ and manganese $(\mathrm{Mn})$ in a complex sporulation medium stimulated spore formation in certain strains of Clostridium botulinum, but sporulation was drastically decreased by the addition of copper $(\mathrm{Cu})$ to the medium (David et al., 1990) and present results are shown in figures $2 a$ and $b$.

Medium containing $500 \mu \mathrm{g} / \mathrm{ml}$ of $\mathrm{MnSO}_{4}$, $\mathrm{ZnSO}_{4}$ and $\mathrm{KCl}$ showed the highest values of both total viable count and heat-resistant spore count compared with other concentrations tested and this is in agreement with a fact that there is a correlation between growth rate and spore yield (Osadchaya et al., 1997).

Varying the metal concentration in the sporulation media is known to influence the thermal- resistance spores due to inducuction of genes coding for the two small acid soluble proteins earlier during sporulation in the media that contained higher metal concentrations (Oomes and Brul, 2004).

In talc formulations, bacterial populations declined steadily over time, the bacteria survived even up to 180 days of storage with different percentage although the population declined from 30 days of formulation. Bacterial population gradually declined from 30 days onwards and continued.

The number of viable cell count was 190 $\mathrm{x} 10^{8} \mathrm{CFU} / \mathrm{g}$ on $30^{\text {th }}$ day, $175 \times 10^{8} \mathrm{CFU} / \mathrm{g}$ on $60^{\text {th }}$ and $90^{\text {th }}$ days after storage of talc formulation. The viable cell counts were 150 $\mathrm{x} 10^{8} \mathrm{CFU} / \mathrm{g}$ on 150 and 180 days after storage. The highest survivable percentage $(88.3 \%)$ of viable cell count was recorded on $30^{\text {th }}$ day. On $60^{\text {th }}$ and $90^{\text {th }}$ day the survivable percentage of viable cell count was 81.4 per cent. The survivable percentage was 69.7 per cent on 150 and 180 days (Table 3 ).

Recent studies on beneficial rhizobacteria have investigated the efficacy of powder formulations in combination with methylcellulose and xanthan gum (Kloepper and Schroth, 1981; Suslow, 1982). Among the formulations, enrichment materials proved to be the most useful as highest number of viable cells were recovered. These are in agreement with previous research which showed that high molecular weight (C6 to C12) compounds such as sucrose and trehalose enhanced survival of bacteria in dried biopolymers (Ilyina et al., 2000).

\section{Evaluation of bioformulation against pest and disease of sericulture field}

Bioformulation was developed to use against mulberry pest- thrips, $M$. phaseolina and $F$. oxysporum by dual culture technique. Inhibition on antifungal assay against $B$. bassiana, M. anisopliae, M. phaseolina, F. 
oxysporum, and antimicrobial activities against silkworm pathogens were also studied.

Effect of antagonistic bacteria against mulberry pest- thrips

The results of the experiment showed that different percentages of bacterial culture were tested against mulberry thrips (Table 4). Population of thrips gradually reduced from first day (60 nos/plant) to 10 DAT (12nos/plant) with maximum reduction seen in 100 per cent culture filtrate, followed by 80,60 and 40 per cent concentrations. On 10 DAT, thrips population was lowest (18 nos/plant) at 80 per cent when compared to 60 and 40 per cent culture filtrates. This trend was observed as the population increased with decrease in the concentration i.e., 23 nos./plant at 60 per cent and 33 nos./plant at 40 per cent concentration respectively. Highest percentage of reduction over control was observed in 100per cent $(86.95 \%)$ followed by 80 per cent $(80.43 \%), 60$ per cent (75.00\%) and 40 per cent $(64.13 \%)$.

Table.1 Total viable cell counts, spore count and spore percentage of $B$. subtilis

\begin{tabular}{|c|c|c|c|}
\hline Time (h) & \multicolumn{3}{|c|}{ Nutrient Agar Media } \\
\hline & $\begin{array}{c}\text { TVC } \\
\left(\times \mathbf{1 0}^{\mathbf{8}} \mathbf{C F U} / \mathbf{m l}\right)\end{array}$ & $\begin{array}{c}\text { HRSC } \\
\left(\times \mathbf{1 0}^{\mathbf{8}} \mathbf{s p o r e} / \mathbf{m l}\right)\end{array}$ & Spore percentage \\
\hline 24 & 65 & 5 & 7.69 \\
\hline 48 & 175 & 18 & 10.2 \\
\hline 72 & 420 & 100 & 23.8 \\
\hline 96 & 75 & 28 & 37.3 \\
\hline
\end{tabular}

TVC: total viable count; HRSC: Heat-resistant spore count

Table.2 Influence of metals on sporulation of B. subtilis

\begin{tabular}{|c|c|c|c|}
\hline $\begin{array}{c}\text { Metals added } \\
\text { at } \mathbf{5 0 0} \boldsymbol{\mu g} / \mathbf{m l}\end{array}$ & $\begin{array}{c}\text { Total viable count } \\
\left(\times \mathbf{1 0}^{\mathbf{8}} \mathbf{C F U} / \mathbf{m l}\right)\end{array}$ & $\begin{array}{c}\text { Heat-resistant } \\
\text { spore count } \\
\left(\times \mathbf{1 0}^{\mathbf{8}} \mathbf{s p o r e} / \mathbf{m l}\right)\end{array}$ & Spore percentage \\
\hline $\mathrm{MnSO} 4$ & 145 & 76 & 52.4 \\
\hline $\mathrm{CaCl} 2$ & 78 & 25 & 32.0 \\
\hline $\mathrm{ZnSO} 4$ & 110 & 45 & 40.9 \\
\hline $\mathrm{KCL}$ & 89 & 56 & 62.9 \\
\hline${ }^{*}$ Mixture & 190 & 183 & 96.3 \\
\hline Control & 93 & 31 & 33.3 \\
\hline
\end{tabular}

*A mixture composed of each of the following: $\mu \mathrm{g} / \mathrm{mL}$ of $\mathrm{MnSo} 4, \mathrm{CaCl} 2, \mathrm{ZnSo} 4$ and $\mathrm{KCL}$ 
Table.3 Effect of carrier and amendments on survival of bacteria in powder formulations

\begin{tabular}{|l|c|c|c|c|c|c|c|}
\hline & \multicolumn{7}{|c|}{ Sampling(days) } \\
\hline \begin{tabular}{c} 
Talc \\
\hline $\begin{array}{c}\text { (x10 }{ }^{8} \text { CFU/g of } \\
\text { formulation) }\end{array}$
\end{tabular} & 215 & 190 & 175 & 175 & 160 & 150 & 150 \\
\hline *Survival (\%) & - & 88.3 & 81.4 & 81.4 & 74.4 & 69.7 & 69.7 \\
\hline
\end{tabular}

*Per cent survival of formulation was determined as follows:

Per cent survival $(\%)=-$

$\mathrm{CFU} / \mathrm{g}$ of formulation at sampling

$\mathrm{CFU} / \mathrm{g}$ of formulation at beginning of experiment

Table.4 Effect of antagonistic bacteria against mulberry pest- thrips

\begin{tabular}{|l|c|c|c|c|c|c|}
\hline $\begin{array}{c}\text { Antagonistic } \\
\text { organism }\end{array}$ & $\begin{array}{c}\text { Culture } \\
\text { filtrate (\%) }\end{array}$ & \multicolumn{4}{|c|}{ Reduction in population } & \multirow{2}{*}{ ROC \% } \\
\hline & & $\mathbf{1}^{\text {st }}$ day & $\mathbf{3}^{\text {rd }}$ day & $\mathbf{7}^{\text {th }}$ day & $\mathbf{1 0}^{\text {th }}$ day & \\
\hline \multirow{3}{*}{$\begin{array}{l}\text { Bacillus } \\
\text { subtilis }\end{array}$} & 40 & 85 & 67 & 45 & 33 & 64.13 \\
\cline { 2 - 7 } & 60 & 69 & 49 & 34 & 23 & 75.00 \\
\cline { 2 - 7 } & 80 & 64 & 46 & 32 & 18 & 80.43 \\
\cline { 2 - 7 } & 100 & 60 & 46 & 28 & 12 & 86.95 \\
\hline & Control & 100 & 96 & 94 & 92 & - \\
\hline
\end{tabular}

Control - Treatment

Reduction overcontrol per cent $(\mathrm{ROC})=$ x 100

Control

Table.5 Inhibition of different bacterial isolates against Macrophomina phaseolina and Fusarium oxysporum

\begin{tabular}{|l|l|l|l|}
\hline $\begin{array}{c}\text { Mycelial growth of the } \\
\text { pathogen (mm) }\end{array}$ & \multicolumn{1}{|c|}{ Bacterial isolates } & $\begin{array}{c}\text { Per cent inhibition } \\
\text { over control }\end{array}$ & $\begin{array}{c}\text { Inhibition zone } \\
(\mathbf{m m})\end{array}$ \\
\hline M.phaseolina & & & \\
\hline $45( \pm 0.11)$ & B. subtilis & $50.00( \pm 0.10)$ & $13( \pm 0.20)$ \\
\hline $50( \pm 0.09)$ & B.tequilensis & $44.44( \pm 0.20)$ & $11( \pm 0.11)$ \\
\hline F.oxysporum & & & \\
\hline $63( \pm 0.07)$ & B. subtilis & $30.00( \pm 0.13)$ & $9( \pm 0.14)$ \\
\hline $69( \pm 0.15)$ & B. tequilensis & $23.33( \pm 0.20)$ & $7( \pm 0.18)$ \\
\hline \multicolumn{1}{|c|}{ Control $(90)$} & & 0.00 & \\
\hline
\end{tabular}

Values are mean inhibition zone $(\mathrm{mm}) \pm$ S.D of three replicates 
Plate 1a. Phylogenetic tree of 16S rRNA gene sequences of silkworm gutbacteria (SGB1). The scale bar represents 1 substitutions/base position.

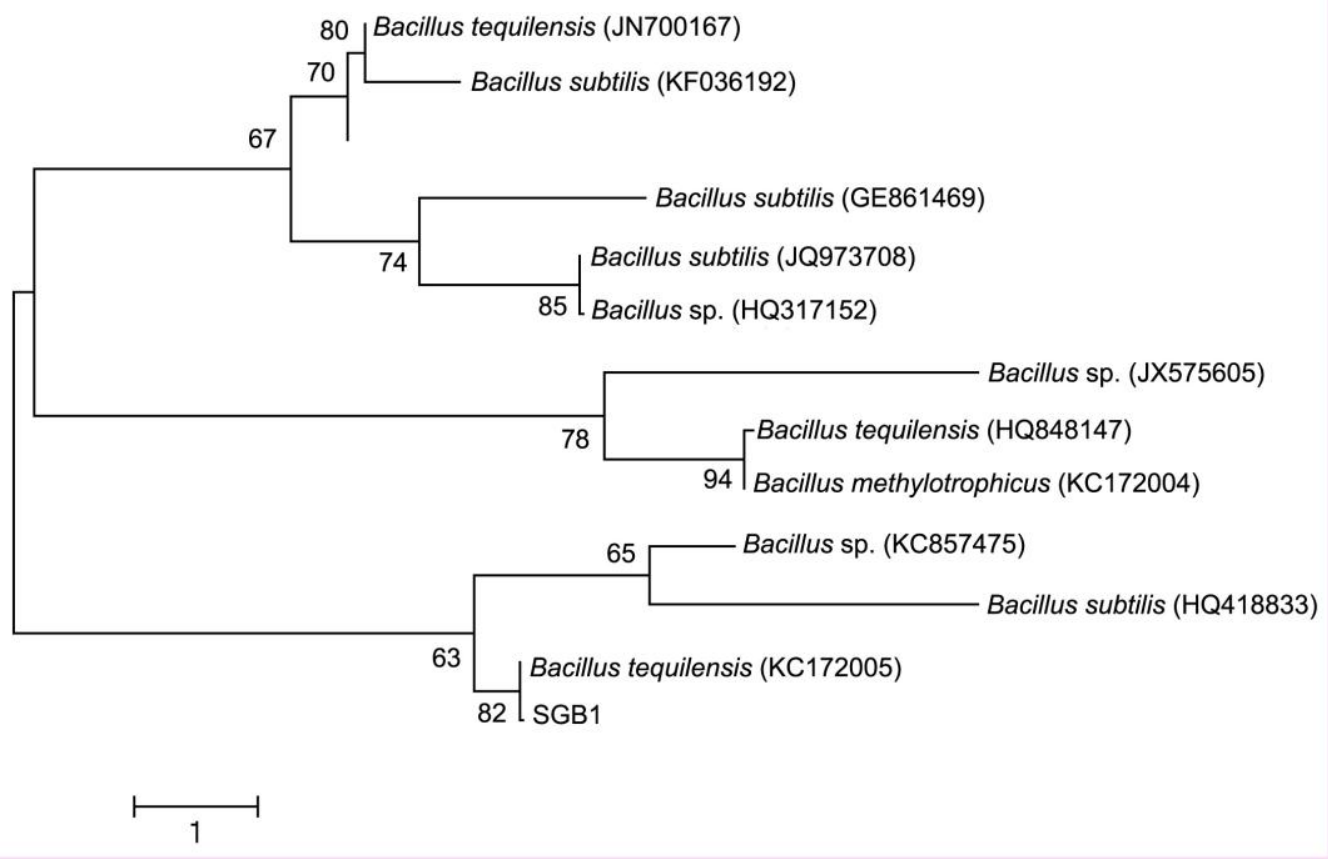

Plate 1b. Phylogenetic tree of 16S rRNA gene sequences of silkworm gut bacteria (SGB2). The scale bar represents 2 substitutions/base position.

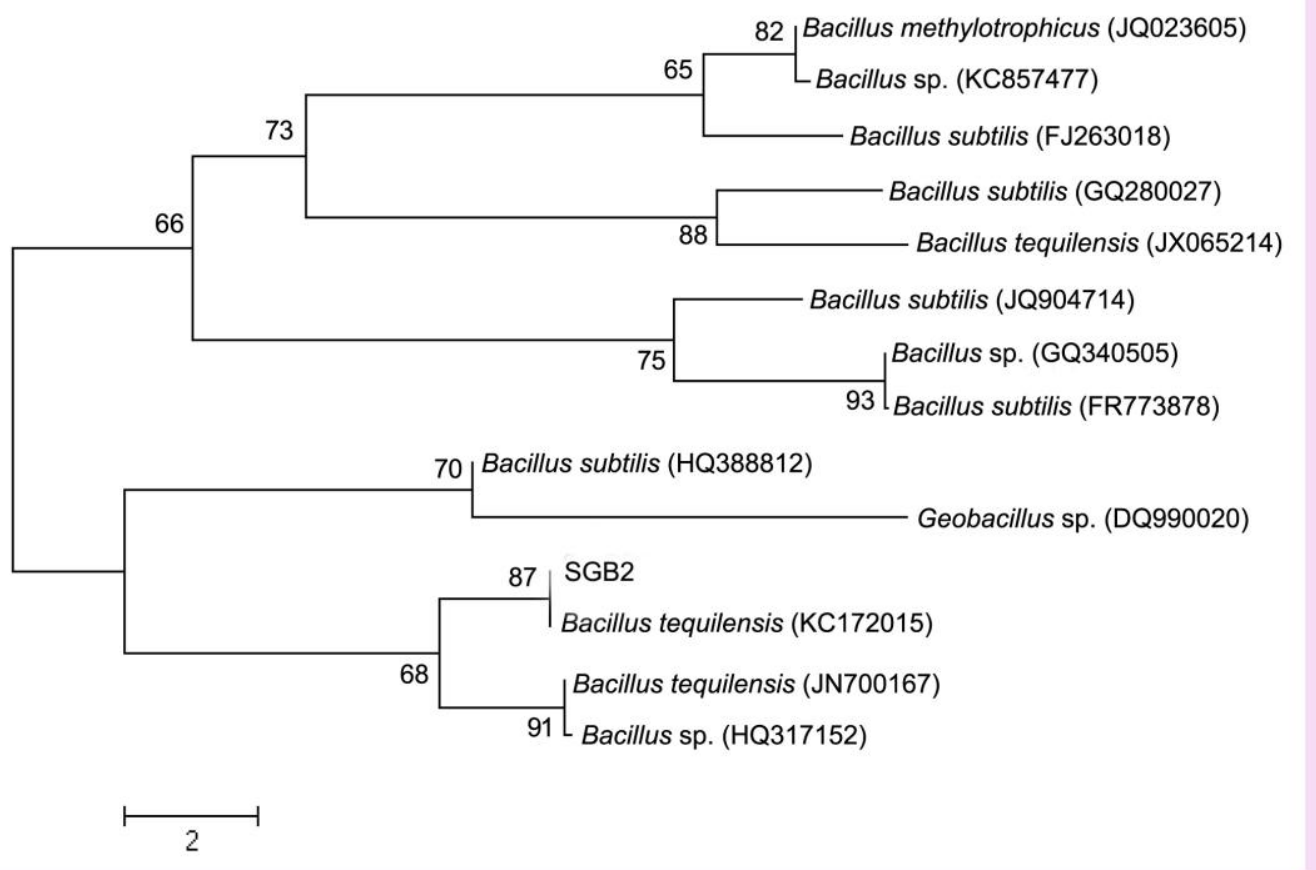


Plate 2. Inhibition of Macrophomina phaseolina by Bacillus subtilis strain SGB1 under in invitro studies

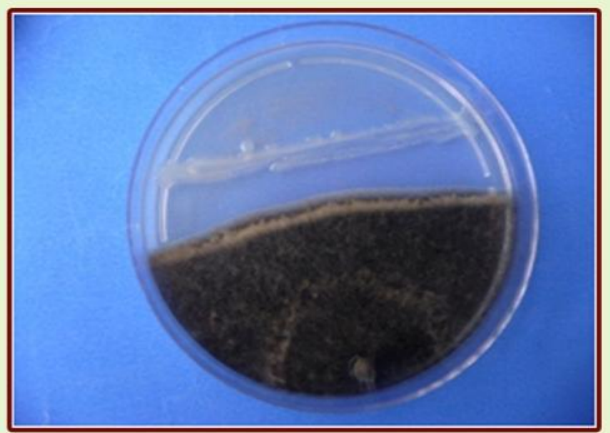

Effective endogenous isolates (SGB 1) against Macrophomina phaseolina

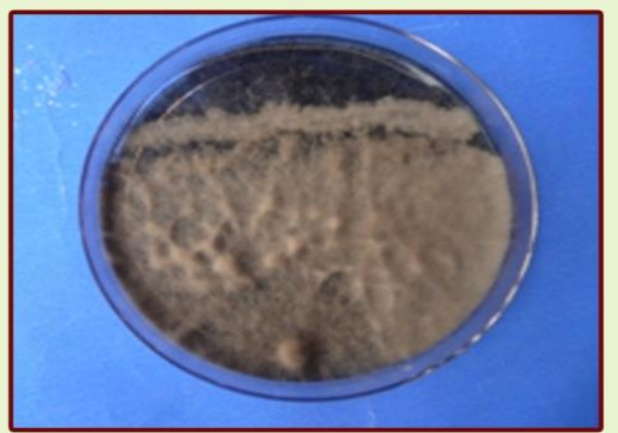

Non effective endogenous isolates against Macrophomina phaseolina

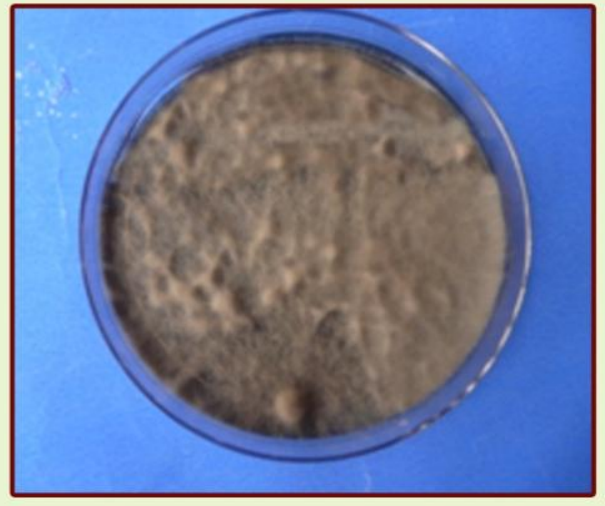

Control 
Plate 3. Inhibition of Fussarium oxysporum by Bacillus tequilensis strain SGB2 under in invitro studies

Treated with Bacillus tequilensis

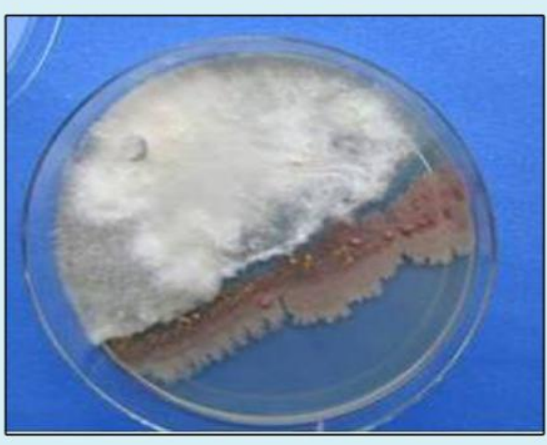

Effective endogenous isolates (SGB 2) against Fussarium oxysporum

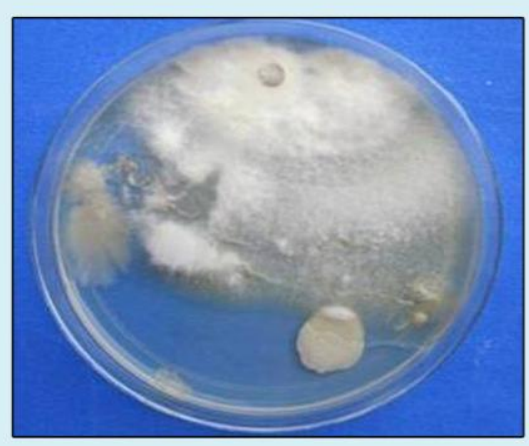

Non effective endogenous isolates against Fussarium oxysporum

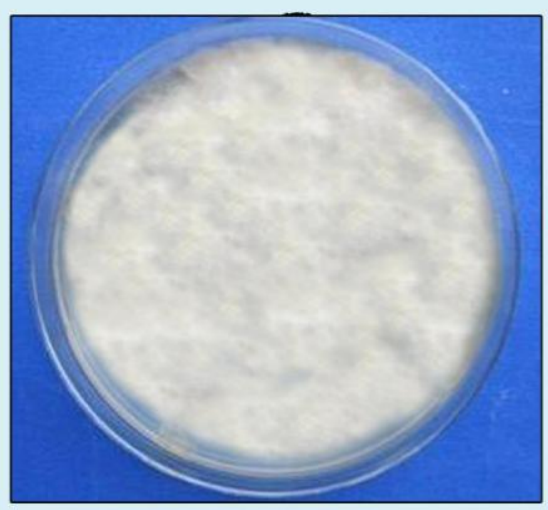

Control 
Inhibition of different bacterial isolates against Macrophomina phaseolina and Fusarium oxysporum

Bacterial isolates of $B$. subtilis and $B$. tequilensis were tested against pathogen of $M$. phaseolina and $F$. oxysporum (Table 5) (Plate 2). The bacterial isolates of $B$. subtilis recorded the least mycelial growth $(45.00$ $\mathrm{mm}$ ) against $M$. phaseolina followed by $B$. tequilensis $(50.00 \mathrm{~mm})$. Mycelial growth of the control was $90 \mathrm{~mm}$.The least mycelial growth of $F$. oxysporum was recorded in treatment with $B$. subtilis $(63.00 \mathrm{~mm})$ and $B$. tequilensis(69.00 $\mathrm{mm}$ ) (Plate 3). The percentage inhibition over control against $M$. phaseolina and $F$. oxysporum was 44.44 and 30.00per cent respectively. The application of B. subtilis recorded maximum inhibition zone of $13.00 \mathrm{~mm}$ forM. phaseolina, and $9.00 \mathrm{~mm}$ for $F$. oxysporum is having the potential to produce more than two dozen antimicrobial active compounds and are mostly antibiotic like peptides. Many of the potent antimicrobial compounds of $B$. subtilis like subtilin, subilosin, basilysin, surfactins are biosynthesized upon sporulation of $B$. subtilis (Stein, 2005).

In conclusion, talc-based powder formulation of Bacillus spores may be effective and ecofriendly management of thrips and root rot disease of mulberry plants.

\section{Further research}

1. Better understanding of silkworm gut microbes function by using molecular and systems-level analysis

2. Insect symbionts would aid to discover novel biocatalysts for biomass deconstruction and develop innovative strategies for pest and disease management

3. Novel antimicrobial protein idenfication would be helped to biomedical science

\section{Acknowledgement}

We special thank to Dr.D.Balachander, Professor, Department of Microbiology, Tamil Nadu Agricultural University, Coimbatore for guided in identified the novel gut bacteria.

\section{References}

Brar, S. K., Verma, M., Tyagi, R. D.,Valero J. R., 2006. Recent advances in downstream processing and formulations of Bacillus thuringiensis based Biopesticides, Process Biochem, 41,323-342.

David J. K., Hutton, M. T., John H. H., Johnson E. A., 1990. Influence of Transition Metals Added during Sporulation on Heat Resistance of Clostridium botulinum 113B Spores. Applied and Environmental Microbiology, 56(3), 681-685.

Dillon, R.J., Dillon, V.M., 2006. The gut bacteria of Insects: Nonpathogenic Interactions. Microbial ecology international symposium, 375-380.

Fages, J., 1990. An optimized process for manufacturing an Azospirillum inoculant for crops. Appl. Microbial Biotechnology., 32, 473-487.

Fages, J., 1992. An industrial view of Azospirillum inoculants. Formulation and application technology Symbiosis, 13, 15-26.

Filho, A.B., Alves, A.B., August, N.T., Pereira, R.M., Alves, L.F.A., 2001. Stability and persistence of two formulations containing Anticarsia gemmatalis Nuclear Polyhedrovirus (AgMNPV). J. Neotrop. Entomol., 30, 411-416.

Ilyina, A. D., Villarreal, S. J. A., Rivera, R. E., Garza, G. Y., Rodrguez, M. J., 2000. Using of biadac. (Absorbent granules produced from paper industry residues) as carrier to microorganisms for soil inoculation. Vestnik Moskovskogo univaesttteta. Khimiya, 41(6), 135-138. 
Kehinde, O. Ademolu., Adewunmildowu, B., 2011. Occurance and Distribution of Microflora in the gut Regions of the Variegated Grasshopper Zonocerus variegatus during Development. Zoological studies, 50(4), 409-415.

Kloepper, J. W., Schroth, M. N., 1981. Development of a powder formulation of rhizobacteria for inoculation of potato seed pieces. Phytopathology, 71, 590-592.

Ohkuma, M., 2003. Termite symbiotic systems: efficient bio-recycling of lignocellulose. Applied Microbiology and Biotechnology, 61, 1-9.

Oomes, S. J., Brul, S., 2004. The effect of metal ions commonly present in food on gene expression of sporulating Bacillus subtilis cells in relation to spore wet heat resistance. Innovative Food Science and Emerging Technologies, 5(3), 307-316.

Osadchaya, A. I., Kudryavtev, V. A., Safronova, L. A., Kozachko, I. A., Smirnov V.V., 1997.,Stimulation of growth and spore formation by optimisation of carbohydrate nutrition during submerged cultivation of Bacillus subtilis. Applied Biochemistry and Microbiology, 33, 286-289.

Schisler, D. A., Slininger, P.J., Behle, R.W., Jackson, M.A., 2004. Formulation of Bacillus spp. for biological control of plant diseases. Phytopathology 94, $1267-1271$.

Stein, T., 2005. Microflora of Galleria mellonella L. Ann. Univ. Marine, CurieSklodowska Sect., 30, 1-14.

Sun, J.Z., Zhou, X. G., 2009. Utilization of lignocelluloses feeding insects for viable biofuels: an emerging and promising area of entomological science. Recent Advances in Entomological Research, T.-X. Liu and L. Kang (eds.), 251-291.

Suslow, T. V., 1982. Role of root-colonizing bacteria in plant growth. In M. S. Mount and G. Lacy (ed.), Phytopathogenic prokaryotes, 1, 187-223.

Tokuda, G., Watanabe, H., 2007. Hidden cellulases in termites: revision of an old hypothesis. Biology Letters, 3, 336339.

Tu, M., Randall, J.M., 2005. Adjuvants. In: Weed Control Methods Handbook: Tools and Techniques for Use in Natural Areas, Hurd and J.M. Randall (Eds.). The Nature Conservancy's Global Invasive Species Team, United States of America. 8, 200-225.

Warnecke, F., Luginbuhl, P., Ivanova, N., Ghassemian, M., Richardson, T. H., Stege, J. T., Cayouette, M., et al., 2007. Metagenomic and functional analysis of hindgut microbiota of a wood-feeding higher termite. Nature, 450, 560- 565.

Warriner, K., Waites W.M., 1999. Enhanced sporulation in Bacillus subtilis grown on medium containing glucose:ribose. Letters in Applied Microbiology, 29, 97102.

\section{How to cite this article:}

Mohanraj, P., C.A. Mahalingam and Raghuchander, R. 2017. Development of Bioformulation and Its Application against Management of Thrips and Root Rot Disease of Mulberry, Morus alba. Int.J.Curr.Microbiol.App.Sci. 6(3): 2438-2449. doi: https://doi.org/10.20546/ijcmas.2017.603.278 